\title{
画像解析による高強度コンクリートの 圧縮破壊性状の可視化ならびに評価
}

\author{
野間 康隆 1 渡辺 健 2 二二羽 淳一郎 3 \\ 1学生会員 東京工業大学大学院 理工学研究科土木工学専攻 (†158-8552 東京都目黒区大岡山2-12-1) \\ E-mail:ynoma@cv.titech.ac.jp \\ 2正会員 東京工業大学大学院助教 理工学研究科土木工学専攻 (同上) \\ E-mail:ken@cv.titech.ac.jp \\ 3フェロー会員 東京工業大学大学院教授 理工学研究科土木工学専攻 (同上) \\ E-mail:jniwa@cv.titech.ac.jp
}

\begin{abstract}
本研究では, 同一水セメント比下で, 単位水量, 単位細骨材量ならびに単位セメント量の質量比で表さ れるモルタル部の配合 (以下, W : S : C), 粗骨材種類ならびに粗骨材絶対容積に依存して高強度コンクリ 一トの圧縮強度が変化する現象を確認した。これら高強度コンクリートの圧縮強度の変化現象を説明する ため, デジタル画像相関法を使用した画像解析を実施した。ひび割れ発生に伴う損傷状況, すなわち画像 解析より得られる載荷直交方向の横ひずみ拡大領域に着目して, 高強度コンクリートの圧縮破壊性状の相 違を考察した。横ひずみ拡大領域のうち, 横ひずみが卓越する領域の分布状況や横ひずみ拡大領域の広さ から, W : S : C, 粗骨材種類ならびに粗骨材絶対容積に依存した圧縮強度の変化現象と圧縮破壊性状の関 連性を示した。
\end{abstract}

Key Words : high strength concrete, digital image correlation method, lateral strain, damage

\section{1. はじめに}

従来，コンクリートの圧縮強度の設計には，水セメン 卜比 (以下，W/C) 則が使用されてきた. しかしながら， 同一のW/C下であるにも関わらず，コンクリートの高強 度化に伴った粗骨材絶対容積の変化により W/C則に即し た現象が必ずしも起こりうることはないことが明らかに なっている ${ }^{1,2)}$ 。これらの圧縮強度の変化については, コンクリート材料の特徵的な力学特性として報告される とともに，起因するメカニズムの解明を目的とした実験 も実施されている.

圧縮強度と圧縮破壊性状の関連性の検討は，わが国で は例えば，和泉ら やや上迫田ら苂により行われている．和 泉らは，コンクリートの圧縮破壊性状の評価手法や問題 点を詳述するとともに, 光弾性皮膜を使用したコンクリ 一トの要素試験を実施している．この実験により，配合， 円孔ならびにモデル骨材の有無が圧縮応力下のひび割れ 進展挙動に及ぼす影響について明らかにし，考察してい る. 一方，上迫田らは，試験体端部の摩擦を除去した場 合の圧縮強度の低減量を圧縮破壊性状と関連付けて議論
している. コンクリートの圧縮破壊は, 縦ひずみの増加 に伴い進行する，応力一縦ひずみ関係では，除々に剛性 が低下して，ピークに達し，ポストピーク領域ではひず み軟化現象を呈する. 試験体には, 微細なひび割れの集 積により成長した縦方向や斜め方向のひび割れが認めら れる.これらのひび割れの発生, 進展によって破壊を評 価することが重要であると考えられる. 既往の研究にお いても，コンクリートの圧縮破壊性状が，このようなひ び割れの発生，進展に着目すべきことを言及している. 同時に，このひび割れの進展挙動を粗骨材やモルタルと いった内部構造を用いて考察している. コンクリートの 圧縮破壞性状を解明する上では，コンクリートを粗骨材 とモルタルから構成される複合材料として取り扱うこと が必要になると考えられる.

本研究では, 再生粗骨材を使用したコンクリートの圧 縮破壊性状の解明も試みる. 従来，コンクリートに再生 粗骨材を使用寸ると高い圧縮強度の増加が見込めないこ とが報告されている5，破壊性状を解明することで，破 壊の抑制，防止手法の提案や，このような材料の適用性 の評価が可能になると思われる. 
表 -1 使用材料

\begin{tabular}{|c|c|c|c|}
\hline \multicolumn{2}{|r|}{ 使用材料 } & $\begin{array}{l}\text { 記 } \\
\text { 号 }\end{array}$ & 物性ならびに成分 \\
\hline セメント & 早強ポルトランドセメント & - & 密度 $3.14 \mathrm{~g} / \mathrm{cm}^{3}$, 比表面積 $4620 \mathrm{~cm}^{2} / \mathrm{g}$ \\
\hline 細骨材 & 小櫃産陸砂 & - & 表乾密度 $2.65 \mathrm{~g} \mathrm{~cm}^{3}$, 吸水率 $1.55 \%$ \\
\hline \multirow{3}{*}{ 粗骨材 } & 青梅産砕石 & $\mathrm{CS}$ & 表乾密度 $2.63 \mathrm{~g} / \mathrm{cm}^{3}$, 吸水率 $0.67 \%$, 最大寸法 $20 \mathrm{~mm}$, 付着モルタル率 $0 \%$ \\
\hline & 高品質再生粗骨材 & $\mathrm{RH}$ & 表乾密度 $2.53 \mathrm{~g} / \mathrm{cm}^{3}$, 吸水率 $2.97 \%$, 最大寸法 $20 \mathrm{~mm}$, 付着モルタル率 $10.0 \%$ \\
\hline & 低品質再生粗骨材 & $\mathrm{RL}$ & 表乾密度 $2.30 \mathrm{~g} / \mathrm{cm}^{3}$, 吸水率 $8.27 \%$, 最大寸法 $20 \mathrm{~mm}$, 付着モルタル率 $52.3 \%$ \\
\hline 混和剤 & 高性能 $\mathrm{AE}$ 減水剤 & - & ポリカルボン酸エーテル系, 密度 $1.05 \mathrm{~g} / \mathrm{cm}^{3}$ \\
\hline
\end{tabular}

ところで近年，各種画像解析手法が開発，提案され， コンクリート構造物の変形解析, 損傷評価ならびに破壊 メカニズムに関する検討に使用されてきているの). こ. れらの手法の利点は，対象物の寸法によらず，コンクリ 一ト表面において生じる面的ならびに局所的に変化する 情報を非接触に計測することができることである。これ まで，計測機器を設置した箇所における変位やひずみの みしか計測できなかったことに対して，計測領域内の任 意の位置における破壊性状の観察が可能になる.

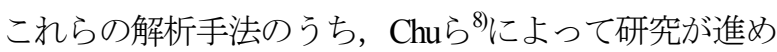
られていたデジタル画像相関法が，セメント系材料の破 壊挙動の評価に適用されてきた9), 10), 11)。この手法は, 画 像中の測定対象物の輝度值がランダムに分布しているこ とを利用し，コンクリート要素，構造物表面の変位を計 測する手法である. 画像中における画素単位の変位の計 算が可能であり，任意の画素の移動量を追跡できる．従 来の画像計測によるひび割れ抽出が1個の画素幅の0.1倍 程度のひび割れ開口変位を有するひび割れを認識可能で あるのに対して ${ }^{12)}$ ，デジタル画像相関法では上記よりも 高精度な変位を計測できたという実験結果がある ${ }^{13)}$, 14). 既往の画像計測と比較し，デジタル画像相関法は，コン クリートに生じる目視では観察困難なより微小な変位や 微細なひび割れを計測できる可能性がある. 本研究で は，このデジタル画像相関法を用いて，コンクリート試 験体表面のひずみ計測を実施する.コンクリート試験体 表面に発生するひずみ拡大領域を用いて，コンクリート の圧縮破壊性状の評価を試みる.

本研究では，上記に示すような同一W/Cの高強度コン クリートで，普通砕石を使用した場合の粗骨材絶対容積 の増加，あるいは再生粗骨材の使用により圧縮強度が変 化する現象に注目する。同一W/C下において，既往の文 献で高強度コンクリートの圧縮強度の影響因子として使 用されてきたW : S : C ${ }^{1)}$ ，粗骨材種類 ${ }^{5}$ ならびに粗骨材絶 対容積 ${ }^{1)}$, 2) が高強度コンクリートの圧縮強度に及ぼす影 響を新たに検討する.

さらに，既往の研究でも議論されてきた圧縮強度と圧 縮破壊性状の関連性より，これら圧縮強度の変化現象の 原因の評価を試みる，そのため，高精度な変位計測が可 能とされるデジタル画像相関法を用いた画像解析により
連結，進展したひび割れの可視化あるいは微細ひび割れ の発生，累積を含めた損傷状況の把握を試夕る。圧縮破 壊により生じる縦方向ひび割れの影響, 言いかえれば, 画像解析より得られる横ひずみの拡大領域に着目して圧 縮破壊性状の相違を評価することを試みる。この際，コ ンクリートを粗骨材とモルタルという2つの相で構成さ れる複合材料として捉えて，この材料の破壊性状を評価 することも試みる.

\section{2. コンクリート試験体の圧縮試験}

\section{(1) 実験概要}

本研究では, 同一W/C下で, W : S : C, 粗骨材種類な らびに粗骨材絶対容積が高強度コンクリートの圧縮強度 ならびに圧縮破壊性状に及ぼす影響を解明することを目 的としている. 強度試験ならびにデジタル画像相関法に より得られた横ひずみを用いた評価を行うための平板試 験体を用いた面内圧縮試験を実施した.

\section{(2) 使用材料}

表一1には，本研究で用いたセメント，細骨材，粗骨 材，および混和剤の物性ならびに成分を示している.

粗骨材として使用する再生粗骨材は，高品質再生粗骨 材と低品質再生粗骨材の2種類である. 本研究で粗骨材 として用いた低品質再生粗骨材は，供用されていた元の コンクリート構造物を解体後に, 発生, 排出されたコン クリート廃材をクラッシャーで破砕して粗骨材部分を取 り出したものである. 一方, 高品質再生粗骨材は, 最近 開発されたスクリュー磨砕装置 ${ }^{15}$ によって，この低品質 再生粗骨材表面に付着したモルタルを除去することで製 作されたものである，このスクリュー磨砕装置は，円筒 形のコーン中のスクリューが回転することにより生じる コンクリート塊相互の接触を利用してモルタル分を除去 するものである.このコーンに再生粗骨材を投入すると， 付着モルタル分が減少した再生粗骨材が製造される. 処 理を数回施すことで，表一1に示すように低い吸水率 (2.97\%)と低い付着モルタル率 $(10.0 \%)$ とすることができ る. なお，本研究で用いた高品質再生粗骨材は，低品質 
表一2 コンクリートの配合

\begin{tabular}{|c|c|c|c|c|c|c|c|c|c|c|c|}
\hline \multirow{2}{*}{ シリーズ } & \multirow{2}{*}{ 配合名 } & \multirow{2}{*}{$\begin{array}{c}\text { 粗骨材 } \\
\text { 最大寸法 } \\
(\mathrm{mm}) \\
\end{array}$} & \multirow{2}{*}{$\mathrm{W}: \mathrm{S}: \mathrm{C}$} & \multirow{2}{*}{$\begin{array}{c}\text { 粗骨材 } \\
\text { 種類 }\end{array}$} & \multirow{2}{*}{$\begin{array}{c}\text { 粗骨材 } \\
\text { 絶対容積 } \\
\left(\mathrm{L} / \mathrm{m}^{3}\right) \\
\end{array}$} & \multirow{2}{*}{$\begin{array}{l}\mathrm{W} / \mathrm{C} \\
(\%)\end{array}$} & \multirow{2}{*}{$\begin{array}{l}\text { s/a } \\
(\%)\end{array}$} & \multicolumn{4}{|c|}{ 単位容積質量(kg/m³) } \\
\hline & & & & & & & & $\mathrm{W}$ & $\mathrm{C}$ & $\mathrm{S}$ & $\mathrm{G}$ \\
\hline \multirow{9}{*}{1} & CS350 & \multirow{18}{*}{20} & \multirow{9}{*}{$1: 5.51: 3.33$} & \multirow{3}{*}{ CS } & 350 & \multirow{18}{*}{30} & 47.1 & 150 & 500 & 826 & 921 \\
\hline & CS450(1) & & & & 450 & & 36.8 & 126 & 419 & 693 & 1184 \\
\hline & CS550(1) & & & & 550 & & 27.7 & 102 & 339 & 560 & 1447 \\
\hline & RH350 & & & \multirow{3}{*}{ RH } & 350 & & 47.1 & 150 & 500 & 826 & 886 \\
\hline & RH450(1) & & & & 450 & & 36.8 & 126 & 419 & 693 & 1139 \\
\hline & RH550(1) & & & & 550 & & 27.7 & 102 & 339 & 560 & 1392 \\
\hline & RL350 & & & \multirow{3}{*}{ RL } & 350 & & 47.1 & 150 & 500 & 805 & 921 \\
\hline & RL450(1) & & & & 450 & & 36.8 & 126 & 419 & 1035 & 1184 \\
\hline & RL550(1) & & & & 550 & & 27.7 & 102 & 339 & 1265 & 1447 \\
\hline \multirow{9}{*}{2} & CS350 & & $1: 5.51: 3.33$ & \multirow{3}{*}{ CS } & 350 & & 47.1 & \multirow{9}{*}{150} & \multirow{9}{*}{500} & 826 & 921 \\
\hline & CS450(2) & & $1: 3.74: 3.33$ & & 450 & & 32.0 & & & 561 & 1184 \\
\hline & CS550(2) & & $1: 1.09: 3.33$ & & 550 & & 16.9 & & & 296 & 1447 \\
\hline & RH350 & & $1: 5.51: 3.33$ & \multirow{3}{*}{$\mathrm{RH}$} & 350 & & 47.1 & & & 826 & 886 \\
\hline & RH450(2) & & $1: 3.74: 3.33$ & & 450 & & 32.0 & & & 561 & 1139 \\
\hline & RH550(2) & & $1: 1.09: 3.33$ & & 550 & & 16.9 & & & 296 & 1392 \\
\hline & RL350 & & $1: 5.51: 3.33$ & \multirow{3}{*}{ RL } & 350 & & 47.1 & & & 805 & 921 \\
\hline & RL450(2) & & $1: 3.74: 3.33$ & & 450 & & 32.0 & & & 1035 & 1184 \\
\hline & RL550(2) & & $1: 1.09: 3.33$ & & 550 & & 16.9 & & & 1265 & 1447 \\
\hline
\end{tabular}

※配合名 : 最初の英文字 2 文字は, 使用している粗骨材種類を示しており, 表一1に示寸記号を用いている. これらの英文字に 付随する数字は，粗骨材絶対容積を示している．末尾に()を伴わない配合は，シリーズ $1,2 て ゙$ 共通の配合であり，( ) を伴う場合は，( )内の数字がシリーズ名を示している.

再生粗骨材に前述の処理を3回施したものである.なお, 本研究で用いた高品質再生粗骨材はJIS A5021「コンクリ 一ト用再生骨材 $\mathrm{H} 」 を$ 満足するものの，低品質再生粗骨 材は, 吸水率が大きくJIS A 5023 「再生骨材Lを用いたコ ンクリート」の規格に適合していない.

\section{(3) 実験シリーズならびに配合}

実験に用いたコンクリートの配合は，表一2に示すと おりである．実験ではすべての配合で同一W/C (30\%) と L, W : S : C, 粗骨材種類ならびに粗骨材絶対容積の3つ の実験因子が，圧縮強度ならびに圧縮破壊性状に及ぼす 影響を検討した. 実験はW : S : Cによって2つのシリーズ に分けて行った. シリーズ1では，W:S:Cが一定であり， 粗骨材絶対容積の増加に伴い, 単位水量ならびに単位セ

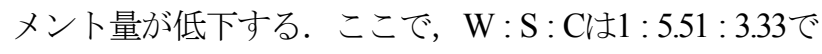
ある. シリーズ2では, 粗骨材絶対容積の増加に伴い, 単位水量ならびに単位セメント量が変化しないように設 定した配合を設けた. 粗骨材絶対容積の増加に従って, 単位細骨材量が低下し, W : S : Cが $1: 5.51: 3.33,1: 3.74$ : 3.33， $1: 1.09: 3.33$ と変化する. 粗骨材種類が同一で，な おかつ使用した粗骨材絶対容積が350 L $/ \mathrm{m}^{3}$ の配合は, い ずれのシリーズにおいても同一の配合を有したコンクリ 一トである. 本研究では，目標スランプおよび空気量は それぞれ $20 \pm 3 \mathrm{~cm} ， 2.5 \pm 2.0 \%$ とした．また，すべての配 合において練混ぜ後, 顕著な材料分離が起こっていない ことを目視で確認した。

\section{(4) 練混ぜならびに養生方法}

練混ぜは，パン型強制練りミキサ(容量 55 L)にて行っ

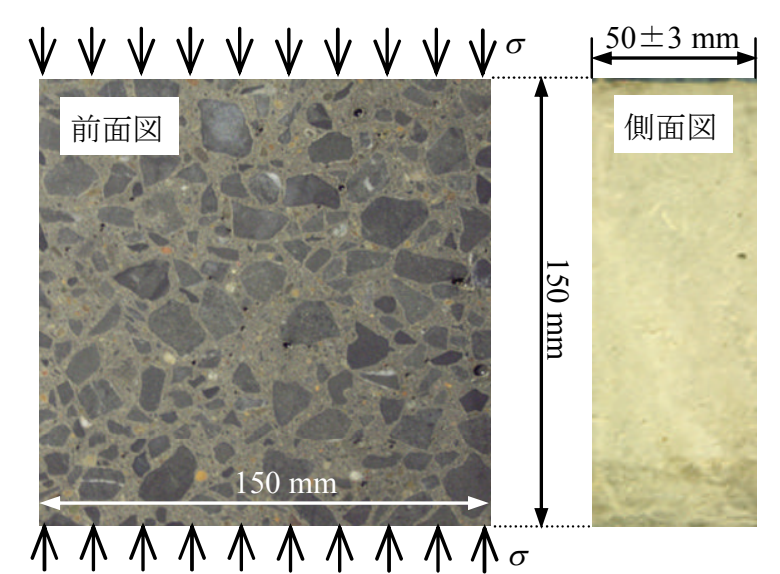

図-1 平板試験体概要図

た. すべてのシリーズで，セメントおよび細骨材を投入 して30秒間練混ぜを行なった後，30秒かけて水を投入し， かき落しを行なった．この後，粗骨材を投入し，120秒 間練混ぜ，排出した。 強度試験用の試験体は材齢7日ま で水中養生を行なった，画像解析用の平板試験体は材齢 6日まで水中養生を行い，その後1日間気中養生を行った.

\section{(5) 試験方法}

所定材齢で圧縮強度をJIS A 1108に準じて測定した. また，デジタル画像相関法を適用するため，図一1に示 すような $150 \times 150 \times(50 \pm 3 \mathrm{~mm})$ の寸法を有する平板試験体 を使用して上下方向に面内圧縮試験を実施した．従来， 型枠面のコンクリートはモルタルで充填されるため, 試 験体表面は均一な色彩となる. 輝度值のランダムな分布 を利用して試験体表面の変位を算出するデジタル画像相 関法では，このような試験体を解析対象とすることは困 難である. そこで，この試験体のデジタル画像相関法に 
よる測定対象面には，輝度值のランダムな分布が現れる ようにする必要がある. このため, 本研究では, コンク リートカッターで得られる切断面を利用することにした. あらかじめ, $150 \times 150 \times 200 \mathrm{~mm}$ の横打試験体を打設した. 養生6日経過後, コンクリートカッターを用いて上記に 示寸寸法を有寸る平板試験体を横打試験体から切り出し て製作した.

このようにして製作した試験体の面内圧縮試験を行い, 高精細デジタルカメラ(画素数 $4368 \times 2912$ )により試験体 の撮影を行った．高精細デジタルカメラは，三脚に固定 して使用した．すべての撮影において，ズームレンズを 使用し，デジタルカメラから被写体までの距離を約500 mmとした. デジタルカメラの焦点距離 $(95 \mathrm{~mm})$ は一定で ある．また，1個の画素幅は，約 $0.057 \mathrm{~mm}$ である，撮影 と同時にノートパソコンに画像を保存した．実験中の太 陽光や電気照明の影響を考慮して, 試験装置全体を暗幕 でおおい，この中で，定電流で駆動する発光ダイオード 照明を使用した。載荷前にキャリブレーションを行い， レンズひずみを補正するためのパラメータとカメラの内 部, 外部パラメータの算出を行った. 載荷開始後, 所定 の荷重ごとに載荷を中断し, 撮影を行った. 加圧面の成 型は行っておらず, 型枠面の平坦性を利用しており, 打 設方向と直交方向に載荷を行った。 なお，減摩パットを 使用すると試験体端部の摩擦が減少するために，奥行き 方向への移動が生じる. 本研究における解析では, 奥行 き方向への変位を生じた場合，これを計測できない，そ のため, 本研究では, 載荷面の端面拘束の影響を除去せ ず載荷を実施することにした。この拘束条件は全試験体 で一律とした.

\section{3. デジタル画像相関法による画像解析}

本研究で使用するデジタル画像相関法 ${ }^{10)}$ では，変形前 の画像中の試験体表面部において選択した任意の画素が 変形後の画像中でどの位置に移動したかを推定すること ができる. 変形後の位置推定を行う際には，清水・奥富 の手法 ${ }^{13)}{ }^{14)}$ を使用した.

図一2には本研究で使用した画像解析の手順を示して いる. あらかじめ, 画像中の試験体表面の測定領域を複 数の3角形要素で要素分割し，デジタル画像相関法を使 用して, 節点に相当する選択された任意の画素の変形後 の画像中における位置を算出した. 本研究では, 図-3 に示すような画像中の平板試験体表面 $2100 \times 2100$ 個の画 素 (約 $120 \times 120 \mathrm{~mm}$ ) の範囲を解析対象としており，この 領域内に縦横 50 個の画素 (約 $2.9 \times 2.9 \mathrm{~mm}$ ) 幅を有する3 角 形要素を縦横42 個配置した. これに付随し, 縦横50 個

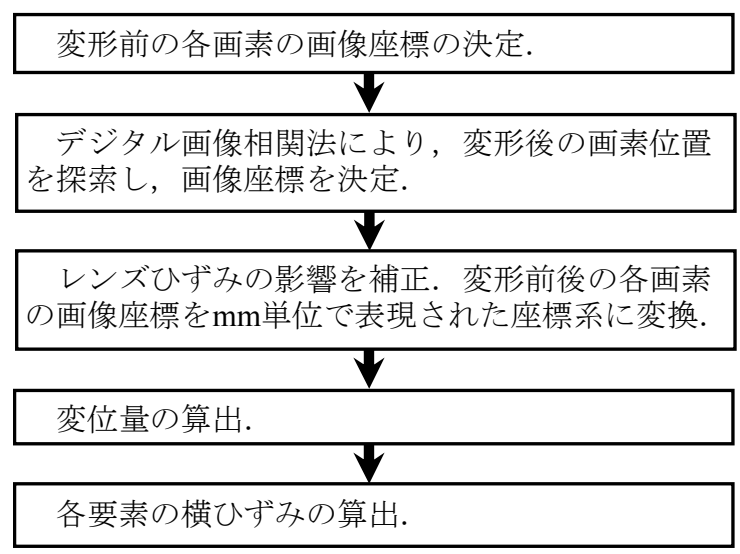

図-2 画像解析の手順

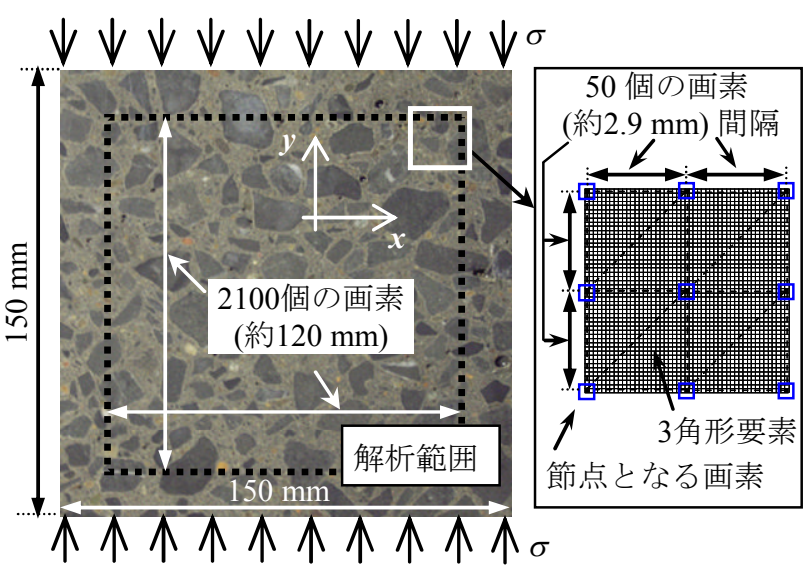

図一3 解析概要図

の画素 (約 $2.9 \times 2.9 \mathrm{~mm}$ ) 間隔で, 縦横43 個の計1849 個の 節点となる画素が選択されることになる. 本研究では, 載荷方向を $y$ 方向，載荷直交方向を $x$ 方向と設定している. 得られた画像座標值にカメラの収差補正を施し, 画像の 歪みによる影響を除去した後 ${ }^{10}$, カメラの内部, 外部パ ラメータを用いて，キャリブレーション時に設定した原 点を中心としたmm単位の座標系に変換する計算を各選 択画素の変形前後の画像座標に施した. 変形前後の上述 したmm単位の座標を元に，定ひずみ3角形要素の形状関 数勇を用い, 要素内の変位を内挿し横ひずみ (図中にお ける $\left.\varepsilon_{x}\right)$ を算出した。 この結果, 試験体表面の局所的な ひずみが計測できることになる，なお，各平板試験体の 最大荷重の $95 \%$ 付近で撮影した画像を対象としている.

既往の文献を参考に寸ると, 本研究で使用した手法の 変位の計測誤差は, 1 個の画素幅の 0.0016 倍になると考 えられる ${ }^{14)}$. 本研究では, 50 個の画素幅を横方向の要 素幅とする定ひずみ 3 角形要素を用いて横ひずみの計算 を行う，上記の誤差が各節点に生じた場合, 横方向に最 大で 1 個の画素幅の 0.0032 倍の変位の計測誤差が生じる と考えられる.この変位の計測誤差を要素幅で除すると， $64 \times 10^{-6}$ のひずみの計測誤差が生じることになる．しか しながら，画像解析を用いて試験体表面の変位計測を行 う際の精度は, 試験体の変形の程度 ${ }^{10)}$, 画像中の輝度值 


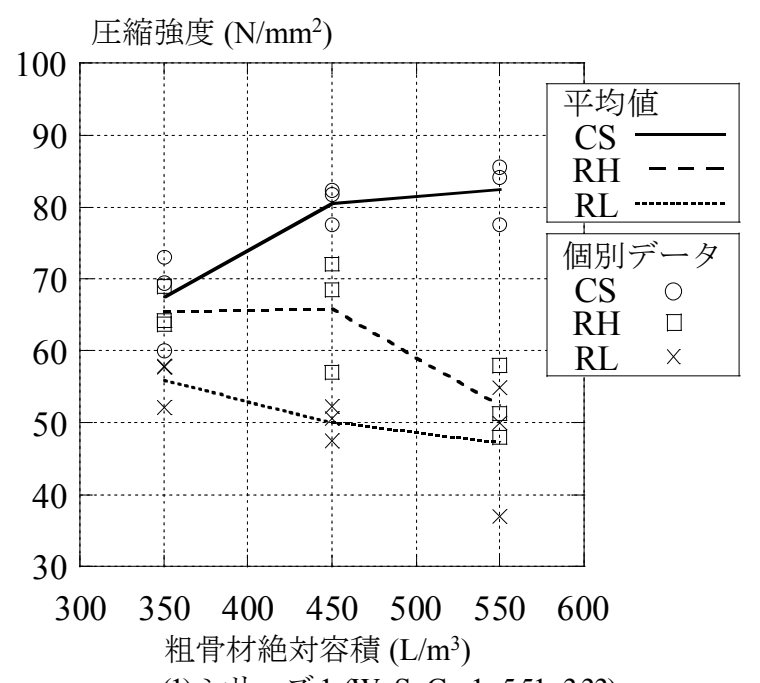

(1)シリーズ $1(\mathrm{~W}: \mathrm{S}: \mathrm{C}=1: 5.51: 3.33)$

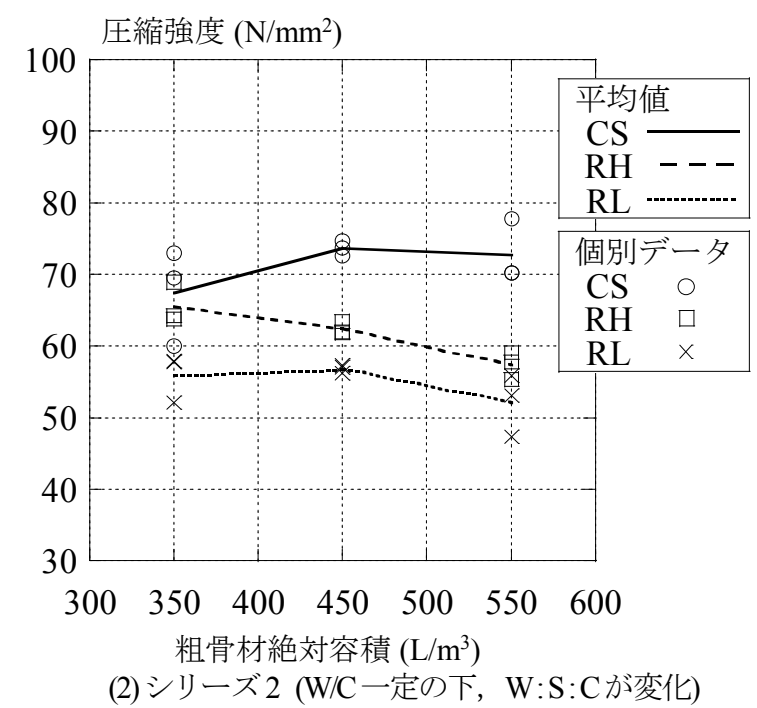

図-4 粗骨材絶対容積と圧縮強度の関係

分布 ${ }^{14)}$ ，デジタルカメラの特性 ${ }^{18)}$ の影響を受けることが 報告されており, 絶対的な変位計測精度を評価すること は困難である.

さらには，デジタル画像相関法を用いて変位計測を行 う場合，変形後の試験体にひび割れのような不連続な部 分が生じると変位計測精度が低下することが報告されて いる ${ }^{19)}$. しかしながら, 本研究と同様にデジタル画像相 関法を用いた画像解析によりコンクリートの圧縮破壊性 状の評価を行った研究では，圧縮何重下でコンクリート 中に生じたひび割れは画像解析による変位計測精度に大 きな影響を及ぼさないと報告されている ${ }^{10)}$.

コンクリートのひび割れ調査では，0.05 mm以上のひ び割れ開口変位を有するひび割れが主に問題となる ${ }^{20)}$. 本研究では，この状態まで進展する以前の $0.01 \mathrm{~mm}$ 以上 のひび割れ開口変位を有するひび割れを観察対象とする ことにした. 今回想定した3角形要素内に $0.01 \mathrm{~mm} の$ 横方 向のひび割れ開口変位が生じると約 $3500 \times 10^{-6}$ の横ひず みが生じることになる，そのため，連結，進展したひび 割れを可視化できる横ひずみ卓越領域を $3500 \times 10^{-6}$ 以上 の引張ひずみを示す領域とした。 また，微細ひび割れの 発生，集積を含めた損傷の領域広さを定量的に評価する ため，横ひずみの值が引張ひずみとして 0 ～ $10000 \times 10^{-6}$ を示す要素を対象として累積百分率による評価を行った.

コンクリート内部の破壊は本来3次元的な現象として 議論されなければならないと考えられる゙．しかしなが ら, 本研究で実施する画像解析では，コンクリート試験 体内部の3次元的な破壊に関する情報を得ることは困難 である. 本研究では，コンクリート表面の2次元的に理 想化した粗骨材やモルタルの配置を対象として，破壊性 状の評価を試みることにした。

\section{4. 圧縮強度試験結果}

図一4は，各シリーズの粗骨材絶対容積とコンクリー トの圧縮強度の関係を示したものである. 圧縮強度は, 各配合の試験体数3体の平均值を直線で示すとともに, 各試験体の個別のデータをプロットしている.

\section{(1) シリーズ1}

シリーズ1では，コンクリート配合中のW : S : Cが全て

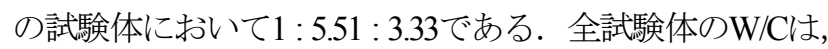
同一であるにも関わらず，粗骨材種類ならびに粗骨材絶 対容積の変化とともに圧縮強度が変化していることがわ かる.

特に，圧縮強度の変化は，粗骨材種類に依存して顕著 になっている. 再生粗骨材 (RHならびにRL)を使用した コンクリートの圧縮強度は，普通砕石 $(\mathrm{CS})$ を使用した高 強度コンクリートの圧縮強度よりも減少する傾向が確認 できる．特に，高品質再生粗骨材を使用するよりも，低 品質再生粗骨材を使用する方が，圧縮強度の低減が顕著 になることがわかる，再生粗骨材を使用した場合，粗骨 材の吸水率の増加に伴い，圧縮強度が低下寸ることが報 告されている5). また，W/Cの低下に伴った圧縮強度の 増加現象が確認できなくなることも報告されている5). W/Cを低下させても，再生粗骨材を使用したコンクリー トの圧縮強度は頭打ちの傾向になるということである5 この結果，コンクリート強度が高い領域では，同一W/C 下であるにも関わらず，CSを使用した高強度コンクリ 一トの圧縮強度と比較して，RHならびにRLを使用した コンクリートの圧縮強度が低下したものと考えられる.

CSを使用した配合では，粗骨材絶対容積に依存して圧 縮強度が顕著に増加していることがわかる (図一4 (1) CS). 粗骨材絶対容積の増加に伴った高強度コンクリートの圧 


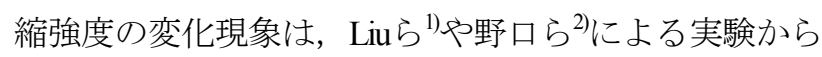
も明らかになっており，本実験でも同様な結果が得られ た．一方，RHならびにRLを使用すると，粗骨材絶対容 積 $350 \mathrm{~L} \mathrm{~m}^{3}$ と比較して, 粗骨材絶対容積 $450 \mathrm{~L} / \mathrm{m}^{3}$ で圧縮強 度が同等あるいは低下し，粗骨材絶対容積 $550 \mathrm{~L} / \mathrm{m}^{3}$ では 明らかに低下寸る結果となった。 (図一4(1)RH, RL).

\section{(2) シリーズ2}

シリーズ2では，コンクリート配合中のW/C一定の下， $\mathrm{W}: \mathrm{S}: \mathrm{C} か ゙$ 粗骨材絶対容積に依存して変化する. 図-4 (2)に示寸通り, シリーズ1と同様にシリーズ2でも，限ら れたデータ数ではあるが，既往の文献の報告と同様に粗 骨材種類ならびに粗骨材絶対容積に依存した圧縮強度の 変化を実際に確認した.

粗骨材種類によって圧縮強度が变化する現象は, シリ ーズ1と同様な傾向にある．再生粗骨材 (RHならびにRL) を使用するよりも普通砕石 (CS)を使用したほうが，コン クリートの圧縮強度が大きくなった.

普通砕石 (CS)を使用寸ると, 粗骨材絶対容積に依存し て圧縮強度が変化する現象が確認できる。しかしながら， シリーズ1と比較し，シリーズ2では圧縮強度の増加現象 が顕著でない傾向にある. また，再生粗骨材 (RHならび にRL)を使用すると粗骨材絶対容積の増加に伴う圧縮強 度の増加がみられない傾向にある。

\section{5. 画像解析結果}

各配合で2体の平板試験体を用い，画像解析を適用す るための面内圧縮試験を実施した。ここでは, 各配合 1 体の画像解析結果しか示していないが，2体目の試験体 の圧縮破壊性状に関しても以下に議論することにした.

ただし，全15配合の内，CS450(1)ならびにRL350の2体に 関しては，同配合の 2 体目の試験体が顕著な奥行き方向 の移動を伴った压縮破壊を呈したため，画像解析を実施

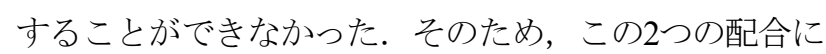
関しては，1体の試験体の結果を用いて, 議論を行うこ ととした.

\section{（1）横ひずみ卓越領域分布を用いたひび割れ性状評価}

図一5ならびに図一6は，平板試験体を用いて実施し た面内圧縮試験の最大荷重の $95 \%$ 時の画像を対象として, デジタル画像相関法により算出した横ひずみ卓越領域 $\left(3500 \times 10^{-6}\right.$ 以上の引張ひずみ)を画像上に青色でマッピン グしたものである. デジタル画像相関法を用いることで, 試験体表面にて連結, 進展したひび割れを横ひずみの卓 越する領域として捉えることができる．斜めに形成され
たひび割れに関しては, 各ひび割れの $x$ 方向とな寸角度 を算出し, 図中に白色の文字で示すこととした. 斜めに 形成された $3500 \times 10^{-6}$ 以上の引張ひずみを示す要素の $\mathrm{mm}$ 単位の重心座標を回帰させて得られた最小二乗直線の傾 きを用いて角度を算出した。試験体表面の横ひずみ卓越 領域の分布状況ならびに横ひずみ卓越領域の存在する相 (粗骨材相あるいはモルタル相) に着目して議論を進める こととした，なお，各図には配合名とともに，図一4に 示している圧縮強度の平均值を示している. 配合名中の 括弧内の数字はシリーズ番号である.

\section{a) シリーズ1}

CS350の試験体では, 図の実線の長方形で囲んだ領域 に縦方向のひび割れのみが生じている (図一5(1) (a)). 上 迫田ら ${ }^{4}$ は，普通砕石を使用した高強度コンクリートの 平板試験体を用い，端部の拘束の影響を除去した面内圧 縮試験において，圧縮破壊した後の試験体には縦ひび割 れが形成されることを指摘している。 この場合, 単位粗 骨材量は800〜1000 kg/m゙ であり, 本研究の粗骨材絶対容 積 $350 \mathrm{~L} / \mathrm{m}^{3}$ に相当するものと考えられる. 端部の拘束の 影響を除去していない本研究の実験でも, 粗骨材絶対容 積350 L/m $\mathrm{m}^{3}$ では縦ひび割れが発生していることが確認で きる. 粗骨材絶対容積を増加させたCS450(1)やCS550(1) の試験体には, 図の実線の長方形で囲んだ領域の縦ひび 割れの他に実線の楕円で囲んだ領域に進展した斜めひび

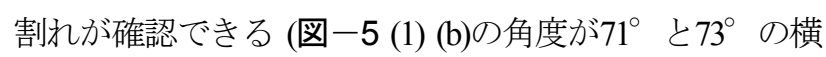
ひずみ卓越領域, (c)の角度が $67^{\circ} ， 72^{\circ}$ と $65^{\circ}$ の横ひず み卓越領域).コンクリート試験体の圧縮試験では, 斜 めにひび割れが発生, 進展し破壊に至ることがある.こ れは, 試験体端部の拘束の影響であることが報告されて いる21). 寸なわち, 目視で観察される斜めひび割れのよ うな破壊現象が見られた場合, 端部の拘束の影響が大き くなっていると推察できる.この端部の拘束が大きいほ ど，コンクリート試験体中に拘束力が発生し, 試験体端 部の横ひずみの増大を抑制する。この結果，コンクリー 卜試験体の圧縮強度が増加することが報告されている. このような端部拘束の影響は, 載荷板の材質や試験体の 寸法比の変化による拘束力の影響を受ける領域の広さに 依存すると考えられてきた。しかしながら，すべての試 験体で同一拘束条件下であるにも関わらず，CS350とは 異なって, CS450(1)やCS550(1)の試験体には, 斜めひび 割れの発生という拘束効果の影響がみられており，圧縮 強度も顕著に増加している。CS350ならびにCS550(1)の2 体目の試験体でも上記と同様な横ひずタ卓越領域の分布 状況が確認できた.

粗骨材にRHを使用した全ての試験体では，図の実線 の長方形で囲んだ領域に1〜3本の横ひずみ卓越領域が確 認できる (図一5 (2)(a)〜(c)). これらの試験体の横ひずみ 


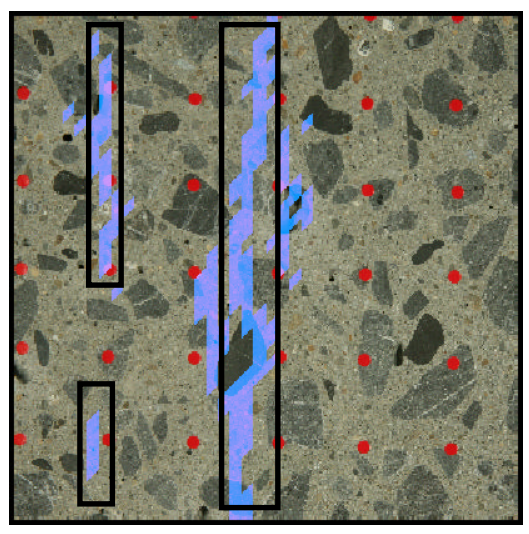

(a) $\mathrm{CS} 350-67.5 \mathrm{~N} / \mathrm{mm}^{2}$

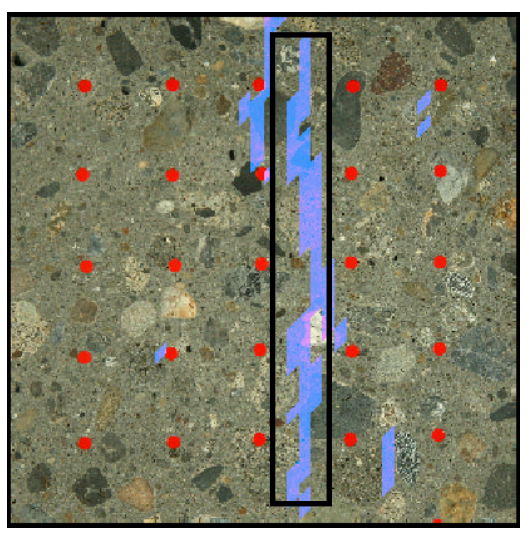

(a) $\mathrm{RH} 350-65.6 \mathrm{~N} / \mathrm{mm}^{2}$

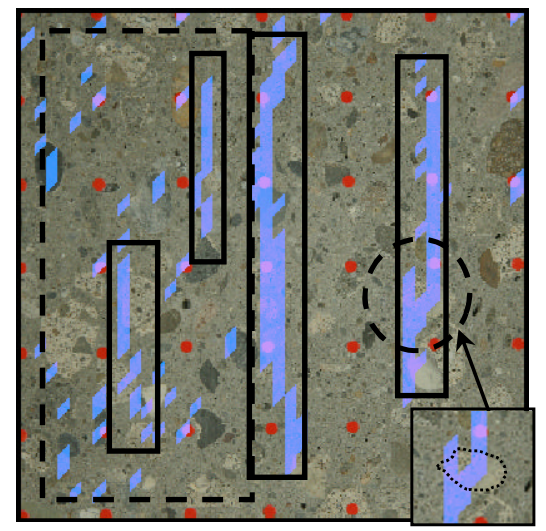

(a) RL350-55.9 N/mm

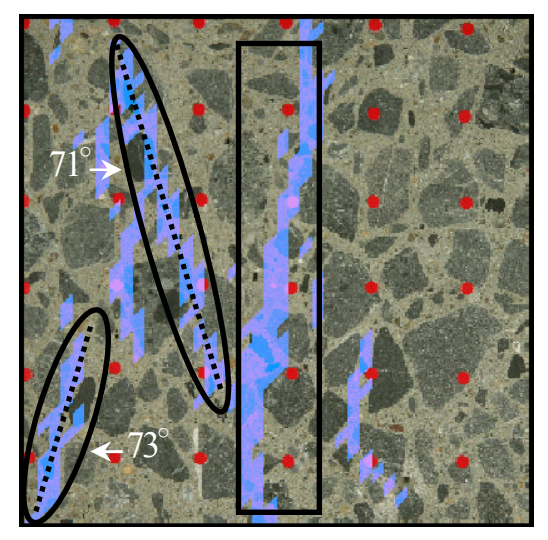

(b) $\mathrm{CS} 450$ (1) $-80.5 \mathrm{~N} / \mathrm{mm}^{2}$

(1) CS

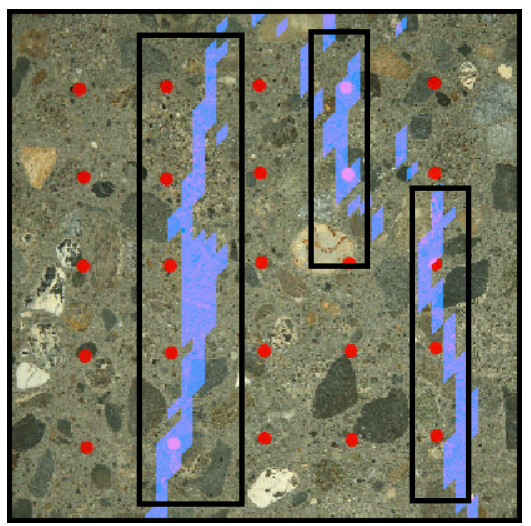

(b) RH450 (1)-65.9 N/mm²

(2) RH

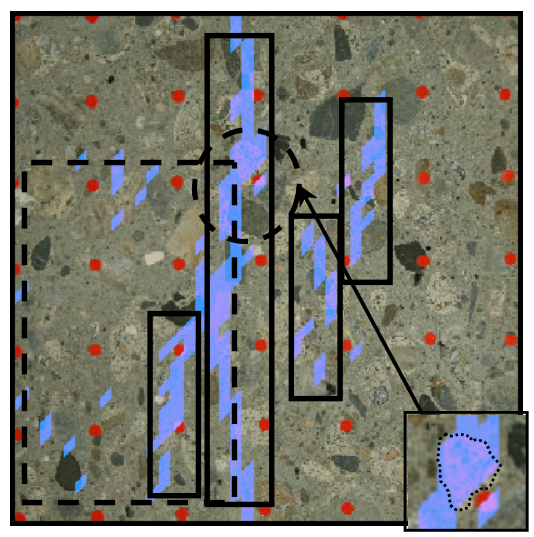

(b) RL450 (1) $-50.1 \mathrm{~N} / \mathrm{mm}^{2}$

(3) RL

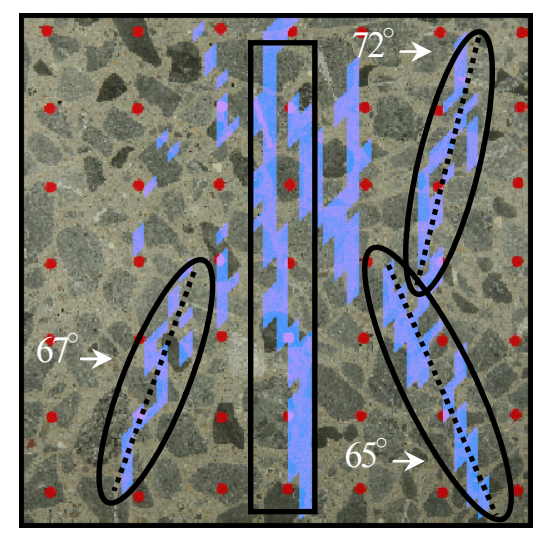

(c) $\operatorname{CS} 550(1)-82.5 \mathrm{~N} / \mathrm{mm}^{2}$

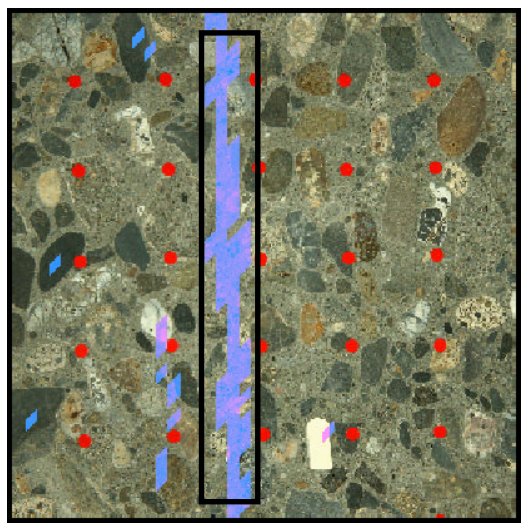

(c) RH550 (1)-52.5 N/mm

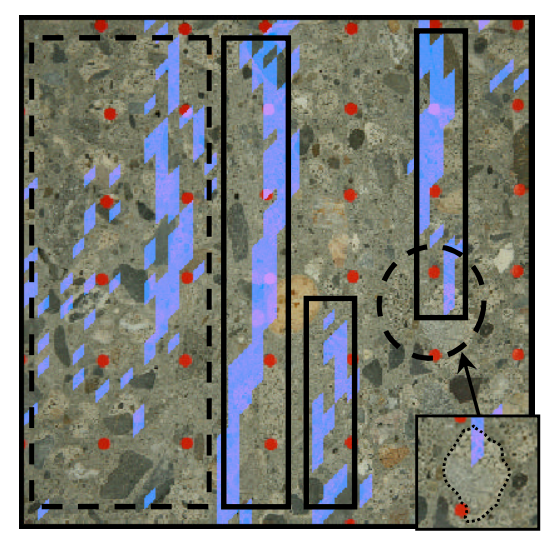

(c) RL550 (1) $-47.3 \mathrm{~N} / \mathrm{mm}^{2}$

図一 5 横ひずみ卓越領域(シリーズ 1$)$

卓越領域分布状況は, CS350の分布之類似している. 粗 骨材にRHを使用した場合，粗骨材絶対容積を増加させ ても斜めひび割れの発生進展は確認できなかった。 また 圧縮強度の増加も確認できなかった．粗骨材絶対容積が 最も大きいRH550(1)では，圧縮強度が大幅に低下した。 RH350，RH450(1)およびRH550(1)の2体目の試験体におい ても斜めひび割れの発生は確認できず，1３本程度の縦 ひび割れと考えられる横ひず夕卓越領域が生じたのみで あった.

粗骨材にRLを使用した試験体では，図の実線の長方
形で囲んだ領域の縦ひび割れ以外に，図の破線の長方形 で囲んだ領域に多数の横ひずみ卓越領域が確認できる. また，破線の円で囲んだ通りコンクリート中の粗骨材相 に存在する横ひずみ卓越領域が確認できる(図一-5 (3) (a) 〜(c)のズームアップした正方形内の破線で囲んだ領域が 粗骨材相). 粗骨材にRLを使用すると圧縮強度が大幅に 低下し，圧縮強度の低下は粗骨材絶対容積が増加するほ ぞ顕著になったＲRL50(1)ならびにRL550(1)の2体目の試 験体でも多数の縦ひび割れと考えられる横ひずみ卓越領 域が確認できた. 


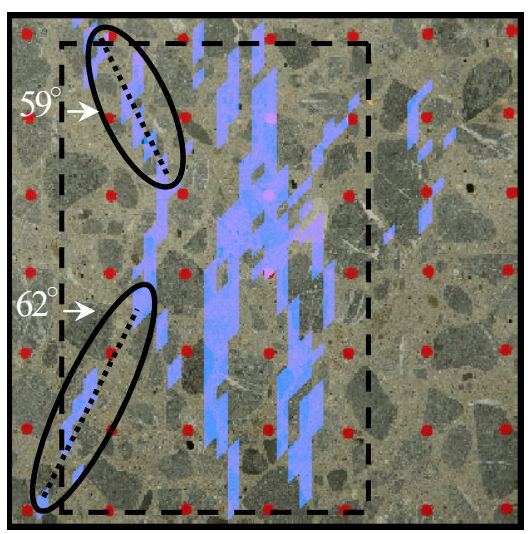

(a) $\mathrm{CS} 450(2)-73.7 \mathrm{~N} / \mathrm{mm}^{2}$

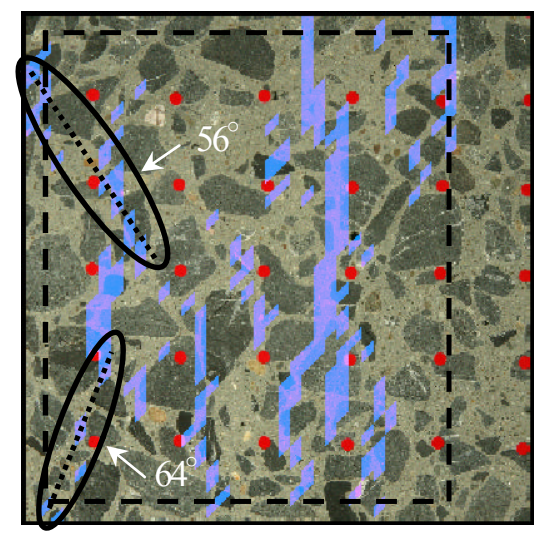

(b) $\operatorname{CS} 550(2)-72.7 \mathrm{~N} / \mathrm{mm}^{2}$

(1) CS

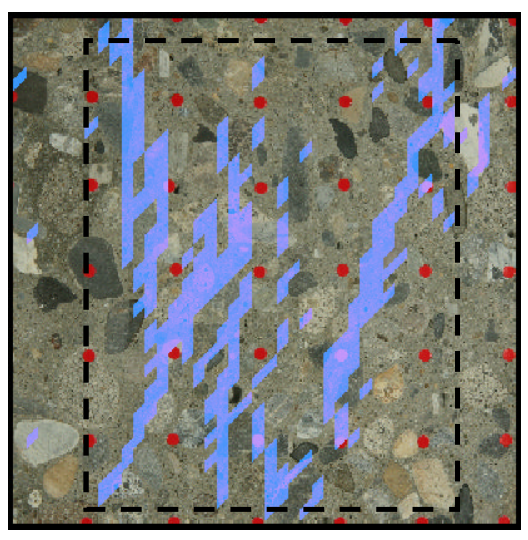

(a) RH450 (2)-62.4 N/mm²

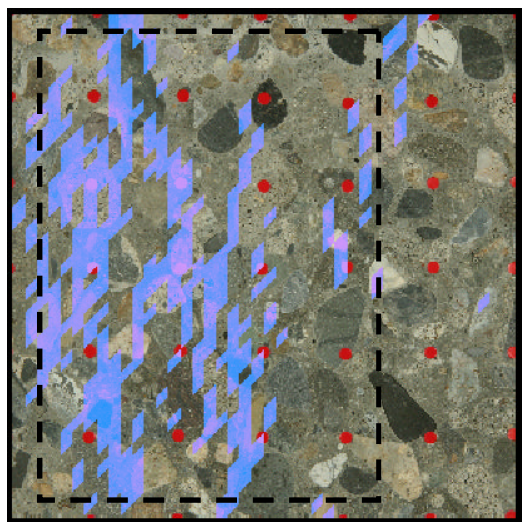

(b) RH550 (2)-57.4 N/mm

(2) $\mathrm{RH}$

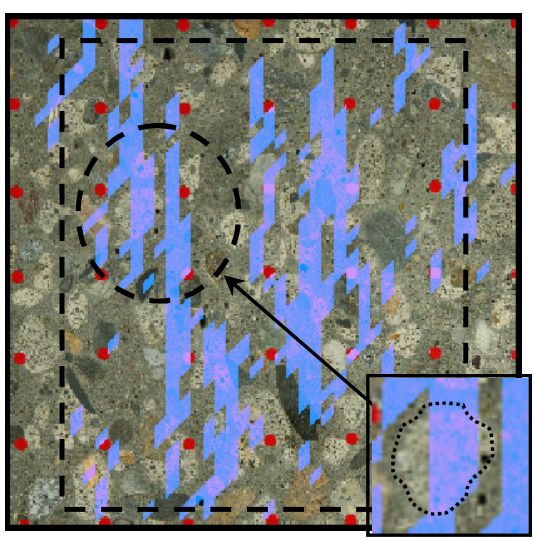

(a) RL450(2)-56.9 N/mm²

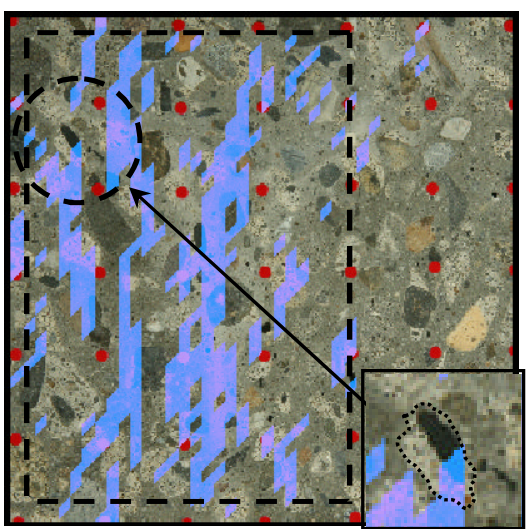

(b) RL550 (2) $-52.1 \mathrm{~N} / \mathrm{mm}^{2}$

(3) RL

図一6 横ひずみ卓越領域(シリーズ 2)

b) シリーズ2

シリーズ2のCS350，RH350およびRL350の画像解析結 果は，既に図一5に示しており，ここでは，これらの配 合以外について考察を行うこととする. シリーズ2のい ずれの試験体でも図の破線の長方形で囲んだ領域に多数 の横ひずみ卓越領域が確認できる.

CSを使用し粗骨材絶対容積を増加させたCS450(2)や CS550(2)の試験体には，実線の楕円で囲んだ領域に進展 した斜めひび割れが確認できる (図一6 (1) (a) の角度が $59^{\circ}$ と $62^{\circ}$ の横ひずみ卓越領域, (b) の角度が56 と $64^{\circ}$ の横ひずみ卓越領域).さらには，図の破線の長方形で 囲んだ領域に多数の横ひずみ卓越領域が存在している. 多数の縦ひび割れの発生により横ひずみが全体的に大き くなると考えられる．横ひずみの全体的な増大により圧 縮強度が低減することが報告されており2)，この多数の ひび割れの進展によって，圧縮強度の顕著な増加がみら れなくなったと考えられる.

粗骨材にRHを使用したRH450(2)やRH550(2)の試験体 (図－6 (2) (a), (b)), ならびにRLを使用したRL450(2)や RL550(2)の試験体 (図一6 (3) (a), (b))には，図の破線の長方 形で囲んだ領域に多数の横ひずみ卓越領域が存在してい る。また，RLを使用した試験体では，シリーズ1と同様 に破線の円で囲んだ通り粗骨材相に存在する横ひずみ卓 越領域が確認できた(図一6(3)(a),(b)のズームアップした 正方形内の破線で囲んだ領域が粗骨材相).

シリーズ2のいずれの配合においても，1，2体目の試 験体のひび割れ状況は類似していた。

\section{（2）横ひずみを用いた損傷領域広さの評価}

デジタル画像相関法を用いた画像解析では，平板試験 体を使用して実施した面内圧縮試験の最大荷重の95\%時 の画像を用いている. 図一7には，横ひずみを用いた微 細ひび割れの発生, 集積をも含めた損傷の領域広さの評 価に使用する累積百分率曲線の算出過程の模式図を示し ている.まず, $100 \times 10^{-6}$ ごとにレンジを区切り，0～ $10000 \times 10^{-6}$ を示す全要素数に対する各レンジの横ひずみ に該当する要素の数の百分率を算出する. 図一7に示す ように，横ひずみが拡大することで損傷した領域が広域 になると, 横ひずみの大きなレンジの百分率が増大する ことになる，図一7に示す通り，同一の累積百分率では， 横ひずみレンジが大きくなるほど，より大きな横ひずみ を示す要素数が増加したことになり, 試験体中の損傷領 域が広域になったことを意味する。横ひずみの拡大に伴 い生じた損傷の領域広さを横ひずみの值を用いて評価す ることにした. この百分率を用いて，ある横ひずみ以上 を示す要素数の0〜 $10000 \times 10^{-6}$ を示す全要素数に対する 
割合を容易に把握することもできる、試験体中では，全 要素はほぼ同じ面積を有している.

図－8ならびに図－9には，各試験体の累積百分率曲 線を示している．横ひずみによって示される損傷領域広 さと圧縮強度の関連性を容易に把握できるように，各グ ラフの配合名と伴に，図一4に示している圧縮強度の平 均值を示した. 配合名中の括弧内の数字はシリーズ番号 を示している. また，比較のために，すべてのグラフに， 一般に使用される高強度コンクリートの配合に近い CS350の結果を示した.

\section{a) シリーズ1}

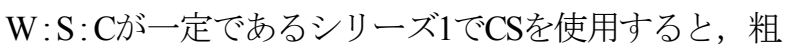
骨材絶対容積の増加に伴って，同一累積百分率における 横ひずみレンジが大きい，これは，試験体表面にて横ひ ずみが大きくなった要素の数が増大していることを示し ている．同時に，圧縮強度が顕著に増加していることが わかる.

RH350の試験体の累積百分率曲線ならびに圧縮強度は, CS350の試験体と同程度である。ただし，粗骨材にCSを 使用するのと比べて，RHを使用すると粗骨材絶対容積 の増加に伴って, 試験体表面に存在する横ひずみの卓越

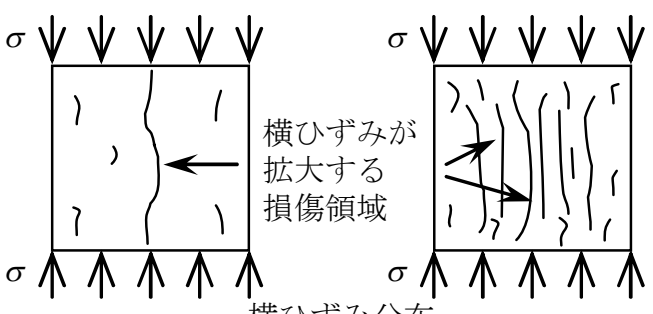

横ひずみ分布
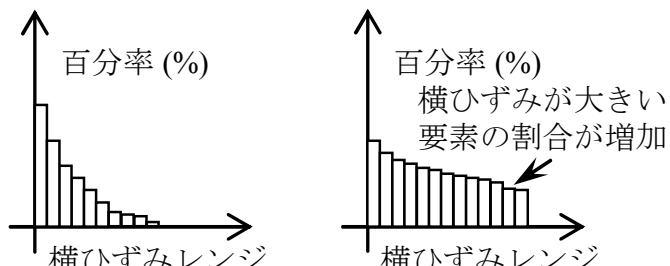

各ひずみレンジにおける要素数の百分率
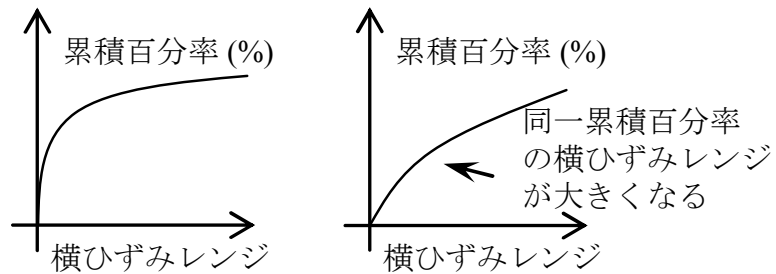

累積百分率曲線
(a) 損傷領域 が狭い場合
(b) 損傷領域 が広い場合

図-7 累積百分率曲線の算出過程(模式困)

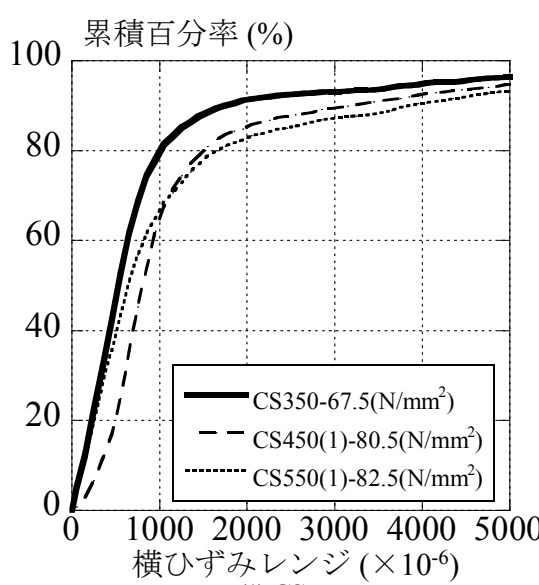

(1) CS

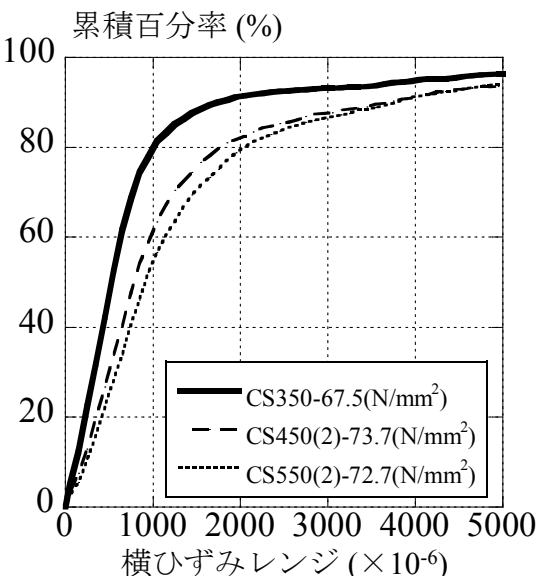

(1) $\mathrm{CS}$

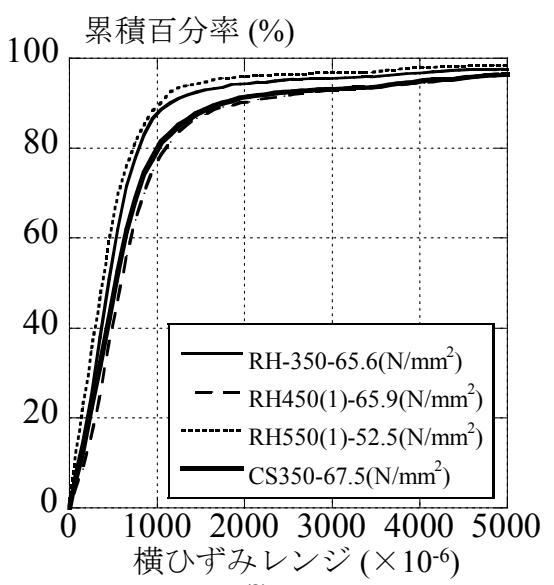

(2) $\mathrm{RH}$

図-8 要素数の累積百分率曲線(シリーズ 1)

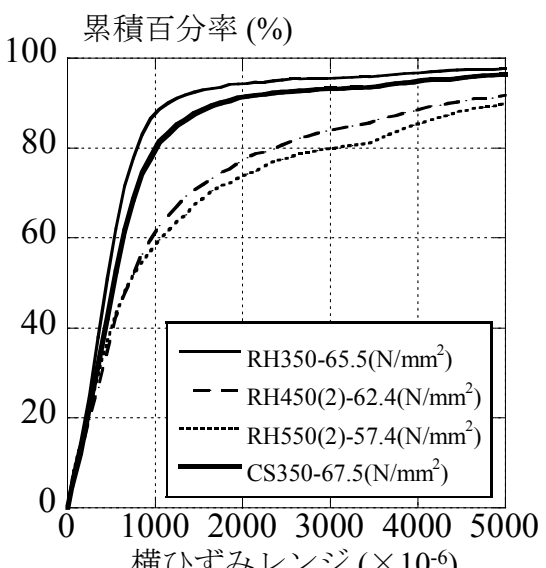

(2) $\mathrm{RH}$

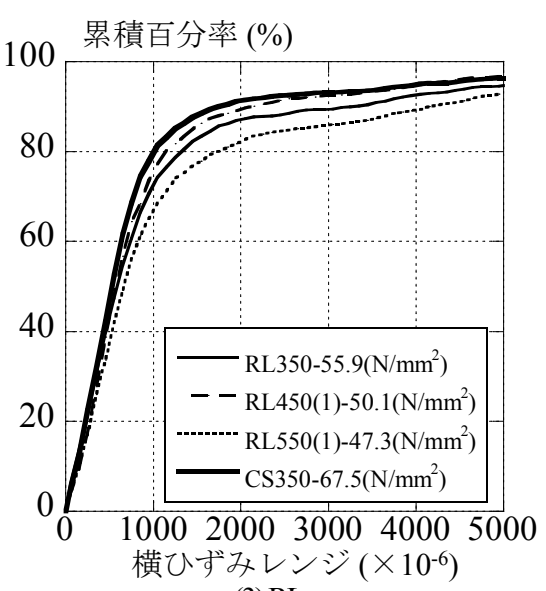

(3) RL

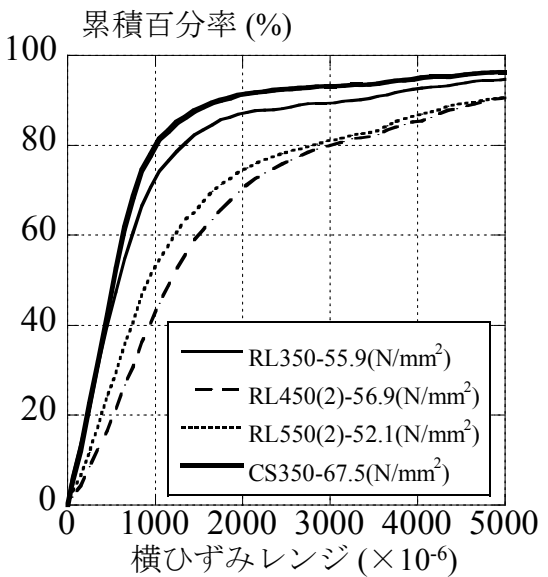

(3) RL

図-9 要素数の累積百分率曲線(シリーズ 2) 
圧縮強度

$40 \mathrm{~N} / \mathrm{mm}^{2} \quad 50 \mathrm{~N} / \mathrm{mm}^{2} \quad 60 \mathrm{~N} / \mathrm{mm}^{2} \quad 70 \mathrm{~N} / \mathrm{mm}^{2} \quad 80 \mathrm{~N} / \mathrm{mm}^{2} \quad 90 \mathrm{~N} / \mathrm{mm}^{2}$

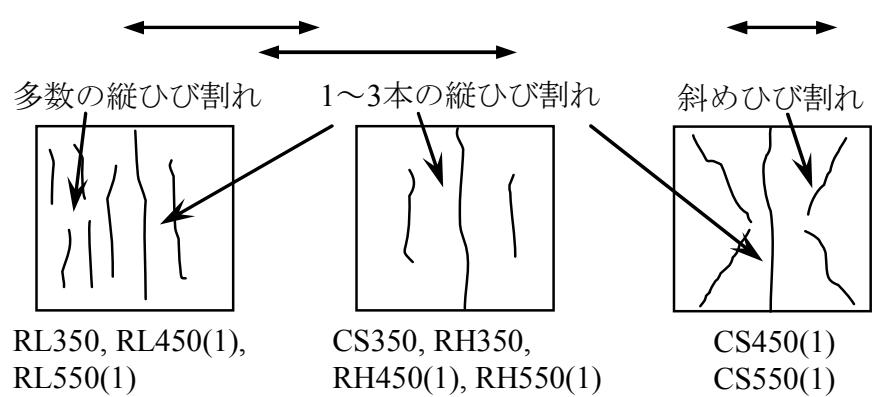

図-10 試験体のひび割れパターン(シリーズ1)

圧縮強度

$40 \mathrm{~N} / \mathrm{mm}^{2} \quad 50 \mathrm{~N} / \mathrm{mm}^{2} \quad 60 \mathrm{~N} / \mathrm{mm}^{2} \quad 70 \mathrm{~N} / \mathrm{mm}^{2} \quad 80 \mathrm{~N} / \mathrm{mm}^{2} \quad 90 \mathrm{~N} / \mathrm{mm}^{2}$

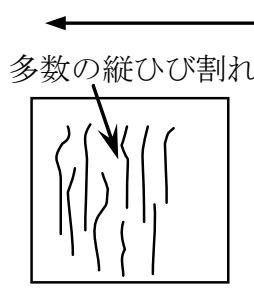

RH450(2), RH550(2)

RL450(2), RL550(2)

図-11 試験体のひび割れパターン(シリーズ2)

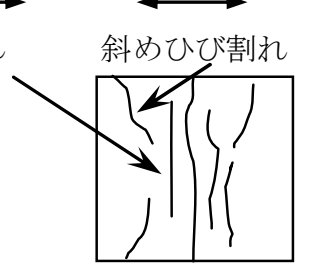

CS450(2)

CS550(2)
した要素の数は大きく変化していないことが確認できる. さらには，粗骨材絶対容積に依存した圧縮強度の増加現 象が見られない.

RLを使用すると，CS350に比べいずれの試験体におい ても同一横ひずみレンジにおける累積百分率が小さく， 横ひずみの卓越した要素が多く存在していることがうか がえる. RHと比較しても，RLの累積百分率曲線では， 同一累積百分率における横ひずみレンジが大きい，また， これとともにCSを使用した試験体と比較しRLを用いた 試験体の圧縮強度は低くなった。

\section{b) シリーズ2}

上述のシリーズ1と比較し，W/C一定の下，粗骨材絶 対容積に依存してW : S : Cが変化するシリーズ2では，い ずれの粗骨材種類でも累積百分率曲線の同一累積百分率 における横ひずみレンジが大きく，横ひずみの卓越する 要素が多くなっていることが確認できる．シリーズ1と 比へ，CSを使用し粗骨材絶対容積を大きくした試験体 では，横ひずみの大きい要素が増大するとともに圧縮強 度の増加が顕著でなくなっている，RHならびにRLを使 用すると，シリーズ1と比べ，横ひずみの卓越する要素 が増加しているものの圧縮強度に大きな変化はない.

RHを使用した試験体と比較して，RLを使用し粗骨材絶 対容積を増加させた試験体の同一横ひずみレンジにおけ る累積百分率が小さく，横ひずみの卓越した要素が増加

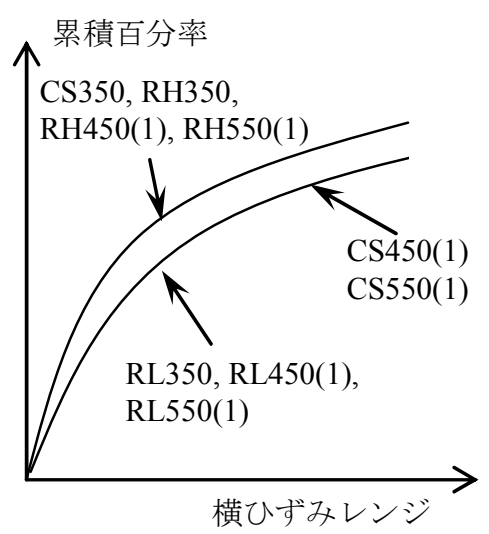

図-12 累積百分率曲線の傾向 (シリーズ 1 )

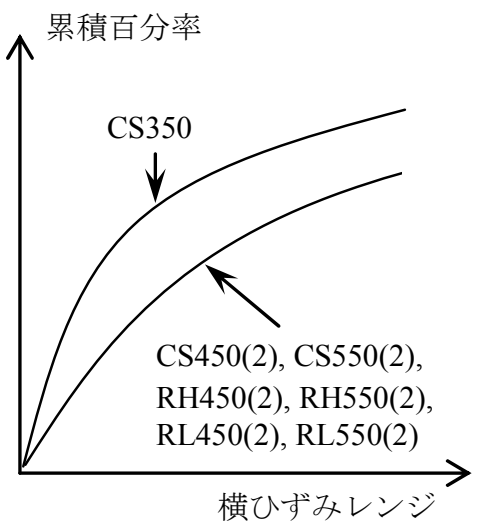

図-13 累積百分率曲線の傾向 (シリーズ 2)

していることが確認できる．CSやRHを使用した試験体 と比べて，RLを使用した試験体の圧縮強度は，大幅に 低下している。

CS450(1)，RL350以外のシリーズ1ならびに2のいずれ の配合においても，同配合における2体の試験体の累積 百分率曲線の各横ひずみレンジの累積百分率の差の絶対 值の全横ひずみレンジにおける平均值は $5 \%$ 以下であっ た. 2本の累積百分率曲線は完全に一致するものではな いが，2体の試験体から得られた累積百分率曲線の傾向 は類似していた。

\section{(3) 画像解析結果を用いた圧縮破壊性状の考察}

図－10ならびに図－11には，試験体表面にて連結， 進展したひび割れのパターン図を圧縮強度と照らし合わ せて示している，また，図一12ならびに図一13には， 各シリーズの各試験体でのひび割れ発生による損傷領域 広さを知ることができる累積百分率曲線の傾向図を示し ている．いずれも，面内圧縮試験の最大荷重の $95 \%$ 時の 情報を用いている.

\section{a) シリーズ1}

圧縮強度が顕著に増加したCS450(1) とCS550(1)の試験 体では，図一10に示すように試験体端部の拘束の影響 により生じる内部拘束の結果，斜めひび割れが発生して いることが確認できた。 さらには，図一12に示すよう 
に横ひずみの増大する要素数が増大していた.これらの 配合では，斜めひび割れの発生が確認でき，損傷した領 域が広域になっていた。

次に, CS350，RH350，RH450(1)およびRH550(1)の試験 体では，図一10に示すように1〜3本程度のひび割れが発 生したのみで，図一12に示すように横ひずみが大きく なる要素数は少なかった. 端部の拘束効果が顕著な場合 斜めひび割れが発生すると考えると，逆に端部の拘束効 果が顕著でなければ, 斜めのひび割れは発生しないと推 察される.これらの配合では，斜めひび割れが確認でき なかったため, CS450(1) とCS550(1)と比較し, 端部の拘 束効果が顕著でなかったのではないかと考えられる.

圧縮強度が小さくなったRL350，RL450(1)および RL550(1)の試験体では，図一10に示すように多数の縦ひ び割れが見受けられ，図一5 (3)からは低品質再生粗骨材 自体に横ひずみの卓越領域が存在していることが確認で きた．また，図一12に示すように横ひずみが大きくな る要素の数が増加した：これらの配合では，CS450(1)之 CS550(1)の試験体とは異なり, 斜めひび割れではなく, 粗骨材を貫通するようなひび割れを含む多数の縦ひび割 れによって横ひずみが大きい要素の数が増加したものと 考えられる.

\section{b) シリーズ2}

圧縮強度がやや増加したCS450(2) とCS550(2)の試験体 では，図一11に示すように斜めひび割れが見られるも のの同時に多数の縦ひび割れも見受けられた. 図一13 に示すように, CS450(2)とCS550(2)の試験体では, CS350 と比較して横ひずみの増大寸る要素数が増加しているこ とが確認された．上述した多数の縦ひび割れを伴い，損 傷領域が拡大したものと考えられる.

図一13からわかるように, CS450(2)とCS550(2)の試験 体と比較して，圧縮強度が低下したRH450(2), RH550(2), RL450(2)およびRL550(2)の試験体では，試験体表面の横 ひずみの増大する領域が増加した。これは，図一11に 示寸ように多くの縦ひび割れが発生していることに起因 していると考えられる.

\section{6. まとめ}

本研究では，同一W/C下で，異なるW : S : C, 粗骨材 種類ならびに粗骨材絶対容積がコンクリートの圧縮強度 ならびに圧縮破壊性状に及ぼす影響について明らかにす るために，実験的検討ならびにデジタル画像相関法を用 いた画像解析を行った．限られたデータではあるが，本 研究で得られた結論は以下の通りである.

(1) コンクリートの圧縮破壞時に発生する観察困難な微
視ひび割れを含めたひび割れ発生による試験体表面の損 傷の位置や程度をデジタル画像相関法を用いた画像解析 により得られる横ひずみを用いて評価できる可能性を示 した.

(2) ひび割れを局所的な横ひずみ卓越領域として可視化 できるデジタル画像相関法を用いた画像解析により, 粗 骨材相とモルタル相のひずタ情報を識別して評価できる ものと考えられる.

(3) 粗骨材絶対容積の増加に伴い, 普通砕石を使用した 高強度コンクリートの圧縮強度は増加傾向を示す. 特に $\mathrm{W}: \mathrm{S}$ : Cを一律にすると増加傾向が著しい. しかしなが ら, 同一W/C下で粗骨材絶対容積の増加に伴いW : S : C を変化させると, 圧縮強度は顕著には増加しない，

(4) 再生粗骨材を用いたコンクリートの圧縮強度は, W : $\mathrm{S}: \mathrm{C}$ 一定にしても変化させても, 粗骨材絶対容積の増 加に伴い圧縮強度は同等かあるいは低下した。

(5) W : S :Cを一定にした普通砕石を多量に用いたコンク リートでは, 試験体表面の損傷領域が広域で斜めひび割 れの発生がみられた. 斜めひび割れが発生し損傷領域が 拡大寸ると, 圧縮強度の顕著な増加がみられた。

(6) W : S : C一定の条件下で高品質再生粗骨材を使用し, 粗骨材絶対容積を増加させた場合, 斜めひび割れが生じ ず，損傷領域の広さが小さくなり，圧縮強度の増加がみ られなかった。

(7) W : S : C一定の条件下で低品質再生粗骨材を使用する と，損傷領域が広域になった，特に，粗骨材相を貫通す るひび割れを含む多数の縦ひび割れが発生し, 圧縮強度 が低下した。

(8) 同一W/C下でW : S : Cを変化させると, 多数の縦ひび 割れとみられる損傷領域が確認された. 多数の縦ひび割 れの発生による横ひずみの全体的な増加は, 圧縮強度の 増加現象には寄与しないものと考えられる。

謝辞 : 本研究を実施するに当り, 太平洋セメント株式会 社から再生粗骨材を提供頂きました. 本研究は, 日本学 術振興会特別研究員の助成を受けて行いました. ここに 記して深謝致します。 また, 本研究の一部は, 平成19年 度科学研究費補助金(基盤研究 (A)，課題番号19206050)に よって実施しました。

\section{参考文献}

1) Liu, Y., Miki, T., Noma, Y. and Niwa, J.: Mechanical properties of high strength concrete, Cement Science and Concrete Technology, Vol.61, pp.412-419, 2008.

2) 野口貴文，小野山貫造，友澤史紀 : 高強度コンクリートの圧 縮強度に及ぼす粗骨材の影響, セメント・コンクリート論 文集，Vol.47，pp.684-689，1993.

3) 和泉正哲, 三橋博三，佐々木達夫 : コンクリートの圧縮破壊 発生機構に関する基礎的研究, 日本建築学会論文報告集, 
No.289, pp.11-25, 1980.

4) 上迫田和人, 前川宏一, 岡村 甫 : コンクリートの一軸圧縮 強度，コンクリート工学年次講演会講演論文集，Vol.4， pp.177-180, 1982.

5) 土木学会 : 電力施設解体コンクリートを用いた再生骨材コン クリートの設計施工指針(案), コンクリートライブラリー, No.120， 2005.

6) 松尾豊史，酒井理哉，松村卓郎，金津 努 : 鉄筋腐食した $\mathrm{RC}$ 部材のせん断而荷機構に関する研究，コンクリート工学 論文集, Vol.15, No.2, pp.69-77, 2004.

7) 町田篤彦 : コンクリートの圧裂試験に関する基礎研究，土木 学会論文報告集, No.279, pp.99-112，1978.

8) Chu, T. C., Ranson, W. F., Sutton, M. A. and Peters, W. H.: Application of digital-image-correlation techniques to experimental mechanics, Experimental Mechanics, Vol.25, No.3, pp.232-244, 1985.

9) 佐川康貴, 尾上幸造, 内野正和, 松下博通 : 一軸圧縮力を受 けるモルタル供試体のひずみ計測へのデジタル画像相関法 の適用性に関する検討, 実験力学, Vol.7, No.2, pp.2026, 2007.

10) Choi, S. and Shah, S. P.: Measurement of deformations on concrete subjected to compression using image correlation, Experimental Mechanics, Vol. 37, No. 3, pp. 307-313, 1997.

11) Van Mier, J. G. M., Meyer, D. and Man, H.: Fracture of quasi-brittle materials like concrete under compressive loading, Advanced Materials Research, Vol.41-42, pp.207-214, 2008.

12) 日本コンクリート工学協会 : コンクリート診断技術’09, 2009.

13) 清水雅夫, 奥富正敏 : 画像のマッチングにおけるサブピク セル推定の意味と性質, 電子情報通信学会論文誌, Vol.J85-D- II, No.12, pp.1791-1800, 2002.

14) 清水雅夫, 奥富正敏 : 領域ベースマッチングのための 2 次 元同時サブピクセル推定法，電子情報通信学会論文誌，
Vol.J-87-D- II, No.2, pp.554-564, 2004.

15) 早川光敬，丸嶋紀夫，石堂修次，飯島眞人 : 製造方法の異 なる再生骨材を用いたコンクリートの調合と特性，コンク リート工学年次論文集, Vol.25, No.1，pp.1247-1252, 2003.

16) Steger, C., Ulrich, M. and Wiedemann, C. (株式会社リ ンクス画像システム事業部訳）：画像処理アルゴリズムと 実践アプリケーション，東京書籍印刷， 2008.

17) Zienkiewicz, O. C. and Taylor, R. L.: The finite element method fourth edition volume 1 basic formulation and linear problems, McGraw-Hill Book Company (UK) Limited, 1989.

18) 内野正和，小金丸正明，山口哲也，米山 聡 : デジタル画 像相関法によるひずみ分布計測(1) (デジタル画像相関法の 高精度化), 日本機械学会 2004 年度年次大会講演論文集 (1), 04-1, pp.293-294, 2004.

19) Poissant, J. and Barthelat, F.: A Novel "subset splitting" procedure for digital image correlation on discontinuous displacement fields, Experimental Mechanics, in press, 2010.

20) 日本コンクリート工学協会 : コンクリートのひび割れ調査, 補修・補強指金十2009，2009.

21) Van Mier, J. G. M., Shah, S. P., Arnaud, M., Balayssac, J. P., Bascoul, A., Choi, S., Dasenbrock, D., Ferrara, G., French, C., Gobbi, M. E., Karihaloo, B. L., König, G., Kotsovos, M. D., Labuz, J., Lange-Kornbak, D., Markeset, G., Pavlovic, M. N., Silmsch, G., Thienel, KC., Turatsinze, A., Ulmer, M., Van Geel, H. J. G. M., Van Vliet, M. R. A. and Zissopoulos, D.: Strainsoftening of concrete in uniaxial compression, Materials and Structures, Vol.30, pp.195-209, 1997.

22) 土木学会 : コンクリート標準示方書[設計編], 2008.

(2009.3.19 受付)

\title{
VISUALIZATION AND EVALUATION OF COMPRESSIVE FRACTURE BEHAVIORS OF HIGH STRENGTH CONCRETE BY USING IMAGE ANALYSIS
}

\author{
Yasutaka NOMA, Ken WATANABE and Junichiro NIWA
}

In this study, influences of the mix proportion in mortar expressed by the mass ratio of unit weights of water, fine aggregate and cement $(\mathrm{W}: \mathrm{S}: \mathrm{C})$, the quality and the quantity of coarse aggregate on the compressive strength of high strength concrete under same water to cement ratio were examined. As a result, the phenomenon that the compressive strength varied depending on these parameters was confirmed. The image analysis using the digital image correlation method was carried out to explain the variation of the compressive strength of concrete. The difference of compressive fracture behaviors of high strength concrete was discussed by focusing on the lateral strain magnification zone obtained by this method. Different distributions of lateral strain concentration zones and damage extents in the lateral direction were observed for each case. The relationship between the variation of the compressive strength and the fracture behaviors was concluded from the distribution and the extent of increased lateral strain zones. 